2020, Volume 14, International Conference Innovative Business Management \& Global Entrepreneurship (IBMAGE 2020), pages: 82-96 |

https://doi.org/10.18662/lumproc/ibmage2020/07

\section{Authentic Leadership, Requirement for Trade Unions in Education}

\section{Gicu-Valentin DOGARU1*}

1 Valahia University from Targoviste, Targoviste, Romania, valentindogaru@yahoo.com

* Corresponding Author
Abstract: The theme of leadership, as much as it has been studied, remains so inexhaustible, the general need to identify those people and styles that lead to good results and that ensure a pleasant working climate. In this context, we considered useful an approach to authentic leadership but applied to trade unions. It may seem like a paradox at first glance, and maybe, for this reason, the topic of union leadership has not been explored much. In the present study, we want to highlight, in general, the perception of teachers about the need for authentic leadership in trade unions in pre-university education in Romania. The need for knowledge of leadership styles, values on which each of them is based, and dangers and the possibility of the emergence of flawed forms, determined this first exploration. The conclusions show that union members appreciate the need for authentic leadership in trade unions in the education system, which can have a positive influence on the educational process.

Keywords: authentic leadership, union, education, perceptions

How to cite: Dogaru, G. -V. (2020). Authentic Leadership, Requirement for Trade Unions in Education. In M. W. Staniewski, V. Vasile, \& A. Grigorescu (vol. ed.), Lumen Proceedings: Vol. 14. International Conference Innovative Business Management \& Global Entrepreneurship (IBMAGE 2020) (pp. 8296). Iasi, Romania: LUMEN Publishing House. https://doi.org/10.18662/lumproc/ibmage2020/07 


\section{Introduction}

In our approach, both explanatory and comprehensive, we start from the assumption that trade unions face different levels of leadership challenges that involve pertinent answers to questions such as: how to use power to enhance or protect established values and establish the certainty that local, county, national trade union organizations will not only survive the democratic slippage but will succeed in placing themselves in a credible, combative and at the same time constructive position? What are the real problems of union members? What strategies would give them the best chance of success? What values, principles need to be promoted in these moments? What impact will the leader's behavior have on the way people perceive those values, those principles? In essence, the heuristic statements mentioned refer to the question: given the problem facing trade unions, how should look like Authentic trade union leadership?

The connotations of the answers are conditioned by the personality's profile of those who are questioned, and by the axiological model established in a frame of reference to their existence. Realizing a regression in time, we notice that the answers are focused on showing people the way, make them followers, it is compulsory to convince people to what they have to do in order to achieve the goals. Show them the way and convince them to follow you in achieving long-term goals such as: "creating a just and just society, ..., developing democracy, supporting workers" [9, p. 13]. It is a model that suggests that union leaders need to formulate a vision, goals to be achieved, strategies and to convince the members to fight for, they also need a system of motivation and appreciation. Leader should also consider ways of maintaining the mobilization of the followers.

The perspective, we consider, is insufficient to respond to the complexity and difficulties that the post-industrial era poses to institutions, implicitly trade unions. What are the consequences if the direction agreed by the union leader is unrealistic, if the proposed vision is captive to personal illusions, if he tries to manipulate the members of the organization to achieve immoral personal goals or if people acquire an unhealthy dependence on the leader and drop down the capacity of own development? What will happen if the members aspire to obtain easy answers and quick solutions, rewarding the charismatic demagogues who have the power and are always ready to give them everything on the tray? Given the possibilities mentioned, we are convinced that a redefinition of the authentic and responsible leader is required, a definition that does not emphasize the dynamics of leader - adherent - goal, but the dynamics of leader - group - 
reality. It can be stated that "... efficient management of the trade union organization must be based on a thorough knowledge of the evolution of all the component elements of the organizational complexity" [27, p. 12].

Wisdom, as perceived in the realm of authentic leadership, doesn't mean to have the answer, it means to look forward it. Usually the question is related with the value of the work and the impact on the quality of life. No less, the individual or group objectives are limited to general social goals and the well-being of the community as a whole. Everyone has to understand the relationship between wisdom and power if they are considering an authentic leadership. In complex organizational, where power is diffuse, leaders must have considerable wisdom to drive through the complicated terrain, full of group dynamics traps, and set in motion processes that focus people's efforts on pressing issues, not outside of them. If he wants to obtain valuable and lasting results, the union leader can rely on a differentiated approach, discipline, co-responsibility, "involvement of subordinates in decision making” [21, p.132]. Its wisdom has the roots in the process to interconnect the real problems with the values and priorities of the people and what are the values that need to be promoted to ensure the best successful chances. Wisdom is a profound form of understanding the functioning of the system in its multitude of hypostases on the axis of temporality.

\section{Problem Statement}

An authentic union leadership that aspires to real progress must define its success according to the degree to which it manages to influence the members to engage in solving issues. What do the members of the unionists do? Do they look at in the face of reality or try to avoid it?

Therefore, authentic leadership requires trade unionists to make adjustments in the value system, in the way of thinking, in the priorities given to responses to threats of different origins, in the way of accepting the new, of taking advantage of emerging opportunities. If they refuse to accept the harsh truths, if they are not able to learn, or if they learn wrong things, then the ability of union members suffers in the process of solving their problems, and unions decline, even perish.

Authentic leaders must lead through the perspective of authentic values, of their own real beliefs, even so their strategies and actions could have elements of strength and weaknesses. The specialized literature is extensive, and this fact is highlighted in. Gardner et al. [7] realize a synthesis of the studies carried out and their conclusions, as well as possible future research directions very useful for us to understand the concept and its applicability. 
Avalio and Gardner [3] conducted an extensive study of the theories of the authentic leader, providing a detailed description of its components. They showed that there are links between a true leader and the organizational culture that have effects on the organization's performance. At the same time, they highlighted the need to understand and implement true performance using a correlation of authentic leadership with authentic leadership [2]. This theory is partially refuted and placed under the conditionality of identifying the follower with the personality and desideratum of the organization [34].

A study of 5 groups of subjects from China, Kenya, and the United States showed, among other things, the existence of a positive relationship between authentic leadership and individual performance [31;32].

Authentic leaders have the purpose and find satisfaction then they manage to lead a group of people towards achieving common goals that will lead to a better world, this being both the challenge and the fulfillment of the authentic leadership [8].

Through their character and determination, authentic leaders can positively influence the well-being and performance of their followers; this is complemented by establishing a univocal relationship between leadermember in enhancing the search for eudaemonist well-being [11]. The personality of the leader is also influenced by his own previous life experiences, experiences to which followers are sensitive, and consider them decisive in his thinking, approach and action, strengthening, and the image of an authentic leader [26].

Several studies have shown the existence of a relationship between authentic leadership and psychological capital, both of which are key elements in stimulating creativity [22]. An authentic union leader seeks workplace performance, job satisfaction, job happiness and organizational commitment that can be fundamentally influenced by the development of psychological capital, which reconfirms the link between authentic leadership and performance $[17 ; 18 ; 19 ; 33 ; 35]$.

Another dimension on which authentic leadership imprints is innovation, a correlation studied and confirmed by Elrehail et al [6] for higher education, which gives us confidence that it can be applicable in preuniversity.

Trust in the real leader, the integrity and coherence between words and deeds, make him better understood by his followers through awareness and assumption of objectives and directions of action. This symbiosis between the integrity of the leader and the conscious actions assumption strongly influences individual and organizational performance, especially in turbulent environments where they inspire stability $[1 ; 14 ; 20]$. 
Exercising authentic leadership creates the conditions that give trade unionists, trade unions, the chance to succeed, in the context of the specific challenge they face. The things that are done must include people, union members, to be moral, constructive, and real. Only in this way can it be appreciated that the trade union and implicitly the leader of the trade union organization is an independent entity, participating in social life, with an autonomous development [24, p.113]. Authentic leader has its development connected to societal needs, which can be illustrated by the model proposed by Luthans, Avolio and Gardner [3; 16].

Wisdom, as understood concerning union leadership, has to balance a multitude of interests and expectations coming from their members, but also the organization itself, in any complex social system: school, local community, and nation. We consider creativity essential for tackling exigent problems and challenges but, no one is wise enough to know what to do every time, nor creative enough to understand every time how to proceed. We appreciate that we must not perceive wisdom as a final state, but as an uninterrupted process of becoming, learning and discovery, a requirement valid for both the union leader and the members of the organization he represents at the local, county, national level. "As a leader, you have to learn all the time, to be flexible, creative and dynamic, charismatic, and surprising" [28, p.159].

A comparative analysis of Authentic, ethical, servant leadership versus Transformational Leadership showed that real leadership is much less about workplace performance and more focused on job satisfaction, organizational commitment, and emotional commitment, which can generate results [10].

In their study Kiersch and Peters [12], using the architecture of authentic leadership and the servant, demonstrate that young people must be educated in the spirit of knowledge and mastery of the following values awareness, impartiality, humility, courage, authenticity, relational orientation, responsibility, withdrawal, acceptance and the like to become leaders of wellperforming organizations. Complementarily, leadership based on ethical value promotes performance in organizations $[2 ; 15]$. The same is true that Machiavellianism can reverse the positive relationship between moral reasoning and authentic leadership, but also between real leadership and moral actions [25]. It reaffirms the need for authentic leaders with a high moral standard.

We perceive authentic union leadership as the normative activity that adds value to the argument by value understanding knowledge, relationships, capabilities, and goods meant to generate well-being, authentic satisfaction and performance. Union leadership has to deal with the moral and ethical components of human, organizational praxis, generalizing, it can be 
appreciated that "the values promoted by leaders exert a significant impact" [23] on the identity of the organization, of its becoming. In the absence of concern for the moral elements of problem-solving and collective effort, the values of the trade union organization may be shattered. To ensure the union's chance to succeed and increase the value of its actions, the union leader must make union members address the adaptive challenges, knowing that "the defining feature of exceptional leaders is to focus on the future" [13, p.37]. An adaptive challenge is a problem that does not disappear even if the leader applies the methods and procedures of solving considered appropriate. Solving the adaptive challenge involves a shift in the system of values and individual and organizational mentalities.

For these reasons, we considered it useful to evaluate the perception of teachers in the pre-university education system about the opportunity for authentic leadership, but also its cooperation with the organization's management and political factors. At the same time, it was wanted to test a possible link of authentic leadership with individual and organizational performance. The novelty of the approach consists in bringing the authentic leadership in the union system, a system by definition oriented towards similar values, but found, at least in Romania in a lethargic phase.

\section{Authentic union leadership}

The effort of a union organization members are making to adapt to the challenges is named adaptive effort and it is the result of systemic learning, imposed by tackling problems. These issues, we believe, often require changing the value system, forming new practices, reviewing priorities. It is no coincidence that the opinion is established that "in an organization, life means becoming, transformation, flow, change, progress, and selfrealization" [5]. The necessary leadership for the adaptive effort of trade unions involves attracting different components of the social system to resolve axiological conflicts, priorities, and reconfiguration, to withstand threats or take advantage of opportunities.

The person who aspires to exercise authentic union leadership through a multitude of adaptive challenges needs considerable wisdom. The mission of authentic union leadership is often to defend or promote new values and practices, as they discourage and gradually abandon old ones that hinder progress. Therefore, the person exercising authentic leadership must know how to choose which values to protect and promote, and which values to question or change. "Leadership qualities are made available ... especially in situations that involve major and rapid changes" [30, p.178]. Therefore, the true leader needs wisdom to post the roper values that are accepted by the 
followers to contribute to the adaptive effort. Wisdom is more than intelligence, it is a mix of intelligence, education, intuition, patience and respect. In nowadays religion and folklore are preserving the wisdom, in other areas being in wane.

To be responsible means, to sum up, the fact of being the cause, agent or source of something, the ability to act without indications or orders coming from a higher position, including making moral decisions and manifesting healthy thinking and judgment. Trade unions, local communities, the general condition of the world, would only benefit if someone took responsibility for being the source of the movement, to help people directly address the reality of the difficulties they are in and address judiciously issues, challenges. In the absence of Authentic and responsible union leadership, trade union organizations perpetuate their dysfunctions anchored in their status quo, which can lead to the dissipation of established organizational and social values over the years through the efforts of people involved and attached.

In essence, authentic union leadership is the option to respond to the problems, dysfunctions, and opportunities that arise in the way of trade unions and communities. Leaders "can make people feel able to act in the direction of the vision" by involving the perception of the future "by accepting the past and managing the present" [4]. Authentic union leadership is the will to be responsible for what happens in the organization, in the community, in the world, to adopt the necessary positions, to intervene at deadlines with honesty and competence. Mobilizing the members to contend the real problems the organization is facing with requires creative, strategic actions and generate solutions that lead to a process built on a moral foundation. In particular, in the exercise of authentic union leadership, meant to make the members of the organization face their adaptive challenges, the union leader must take responsibility for:

- the evaluation of the challenges they have to face individually or as organization and to find our if they are prepared for that confrontation;

- the implementation of the solving process. People's activity means interrogating reality, resolving conflicts in the sphere of values and priorities, adopting new practices that solve undecided situations and open the way to authentic progress;

- the power he is representing. The leader must be aware of how he is using the power he is invested to manage the problems they have to address. He is using the authority, presence, and interventions to influence the thinking and actions of those around him when they abandon their challenges. 
Exercising authentic union leadership helps members of the organization meet challenges, to identify the real problems, to prioritize the goals, to select the best way of action, to ensure the trade unions they represent the best chances successful. "The leader must have a sense of the unknowable (of the unknown) and be able to see the unpredictable" [29, p. 117].

Authentic leadership calls for the mobilization of all factions, which must take their share of the effort to change values, skills, practices, and priorities, for reform to begin slowly, slowly. The adaptive effort is timeconsuming, and the rhythm in which it is deposited must be carefully adjusted so that people can make the necessary adjustments in the face of new realities.

In conclusion, we appreciate that authentic leadership: has nothing to do with domination and control, do not impose false targets or force people to achieve them, do not compel people to accept opinion they are not confident with, even if they are based on moral convictions, they should not stay in a comfort zone they already know.

In the absence of authentic leadership, it falls easily into counterfeit leadership and triggers mechanisms of misallocating attention, resources, and time. This could lead to a false set of goals, objectives not related with progress and well-being, but they can distract people from their path. The purpose of authentic union leadership is to make people face the most difficult challenges head-on, not to pursue false targets. To achieve this, the leader of the union needs to go through certain steps like analyzing the situation and context, diagnose, and reveal the real threats and opportunities in front of the members. He is responsible to drown an action strategy based on the problem and organization resources. Another mission he has, is to polarize the actors of the social system it leads, make them go through the process of analyzing the situation, and solve the problem, ensuring them real chances of success. It is a laborious and demanding activity, but it is not a more important one for the strength, credibility, and visibility of the union organization.

\section{Research methodology}

For a satisfactory connection to the union leadership to the perception and expectations of the teaching staff in pre-university education, an opinion poll was conducted between March and September 2019. The survey included a set of 20 questions from which we selected the following:

Q1 How do you rate your union leader's performance on a scale of 1-10? 
Q2 Does joining a union structure help you in your work from the perspective of professional performance?

Q3 Is your union leader Authentic?

Q4 Do you think that the existence of a Authentic leader would positively influence the performance of the organization?

Q5 To what extent does your union leader cooperate with the organization's management on a scale of 1-10? Do you appreciate this collaboration as beneficial to the organization's performance?

Q6 To what extent does your union leader cooperate with political actors in the region on a scale of 1-10? Do you appreciate this collaboration as beneficial to the organization's performance?

Q7 Do you consider that authentic leadership is needed at the national level?

The sample was selected randomly from all over the country, without pursuing a territorial representation. The number of respondents was 273 out of a total of about 215 thousand teachers. We can consider that the sample is representative because the studied community is sizeable, and the sample has the necessary size for a probability of guaranteeing the results of $95 \%$ and an error of $+/-6 \%$.

\section{Findings}

For questions Q1, Q5, and Q6, we used a scale from 1 to 10. Respondents assessed the performance of the union leader and his cooperation with the management of the organization and local political factors.

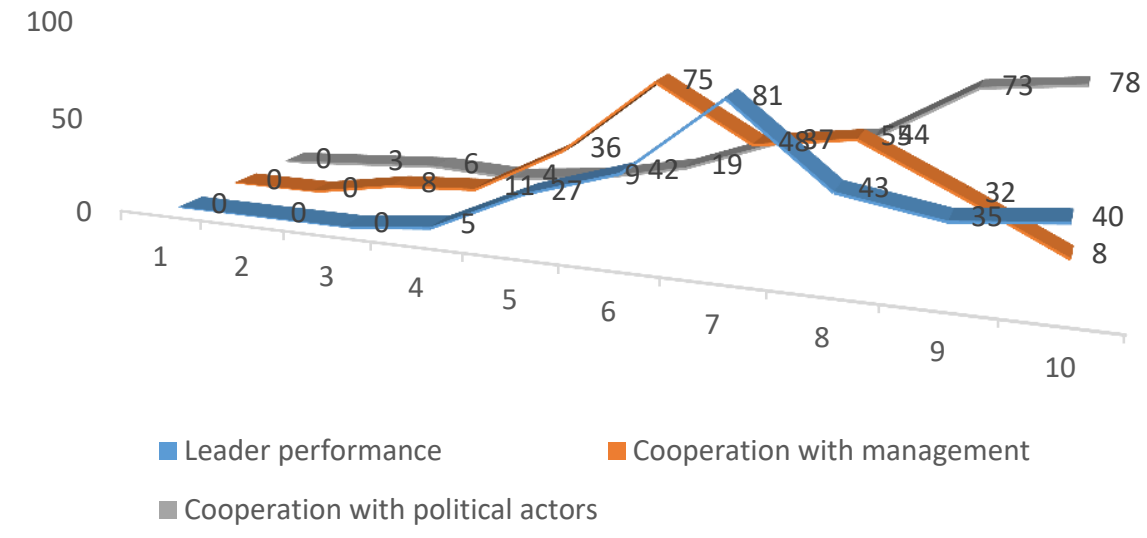

Figure 1 Answers distribution for Q1, Q5, Q6

Source: Author results representation 
From figure 1. it can be seen that for the leader's performance the distribution is almost Gaussian from 4 to 10, with a maximum placed at 7 . The distribution of answers is similar in the case of assessing cooperation with the organization's management. As ab exception, the first values are recorded at the value 3 , and the maximum is placed, this time at 6 .

If we consider that an appropriate performance, as well as an easy collaboration, is placed from eight upwards, the results show that $43.2 \%$ are satisfied with the union leaders, and $34.8 \%$ appreciate that there is a collaboration between them and the organization management.

Questions Q2, Q3, Q4, Q7, and Q5s, Q6s (follow-up questions) were dichotomous to have an assessment of the main direction of opinion in the educational environment.

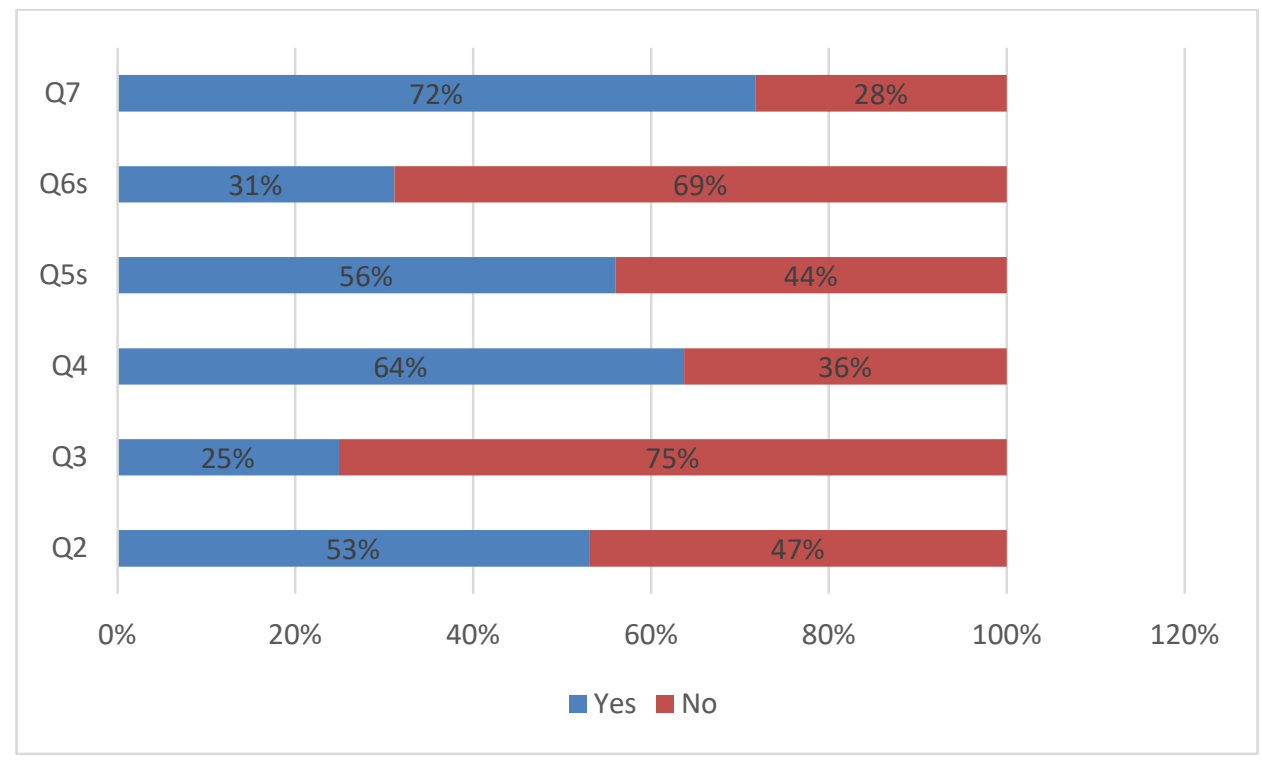

Figure 2 Answers distribution for Q2, Q3, Q4, Q5s, Q6s, Q7

Source: Author results representation

For the subsequent questions regarding the collaboration with the management of the organization, the political factors, and the positive effect on the performance of the institution, it can be seen that it is in favor of collaboration with management (Q5s) and against collaboration with political factors (Q6s). For Q5s, given that the error is $+/-6 \%$, the result is not relevant, as it can oscillate between yes and no, which leads us to the conclusion that there is no well-formed opinion. 
A similar situation occurs in Q2, where the result is not relevant in terms of a positive effect on performance due to membership of a trade union structure.

Respondents' opinion on the existence of Authentic leaders is unfavorable $75 \%$ consider that they do not have a real leader, although $64 \%$ consider that the existence of authentic union leaders would positively influence the institutional performance.

At the same time, the degree to which they consider it necessary to have authentic trade union leaders at the national level is even higher $(72 \%$ compared to $64 \%$ ).

\section{Conclusions}

A first conclusion could be that there is no formed opinion on the positive effects of a collaboration between union leaders and the management of the organization. We can speculate that teachers are afraid of possible agreements between them, which could be against their interests. The current of opinion unfavorable to the collaboration between union leaders and political factors is clearly outlined $(69 \% \mathrm{NO})$. In this case, we can speculate that this opinion is based on several elements such as distrust of the political class, unnatural agreements of leaders to the detriment of members, previous examples of turning union leaders into politicians, affecting the "union struggle" for electoral political interests.

The lack of a well-defined perception, in favor or against belonging to a trade union structure and its beneficial effects, leads us to the conclusion of the fragility of trade unions caused by legislative changes in the last 20 years, but also of poor trade union leadership. This is also confirmed by the result obtained for Q3, which shows that three-quarters of the leaders are perceived as not being authentic.

We can appreciate that the need for authentic leaders is associated with the subjects with a better representation of them in the sense of increasing job security, improving working conditions, increasing salaries, opportunities for personal development and career path.

We can define the authentic union leader as the leader who makes people face reality and what it entails in terms of the conditions, threats, and opportunities they face; mobilizes the entire organization in adapting and adjusting values, skills, practices, and priorities; seeks to acquire the knowledge and wisdom it needs to lead the members of the organization; assumes responsibility as a generator of the trade union movement.

On the other hand, the counterfeit leader excessively insists that people obey him, resort to domination as a control mechanism, fails to 
engage the group and its various factions, does not have the will to seek solutions located outside its comfort zone and beyond its dominant paradigm, and he is convinced that he is the only one who holds the truth and knows the way forward.

In the absence of development and adaptation to the current requirements of the socio-economic environment, there is a risk of a significant segment being captured by counterfeit leadership and the organization's orientation towards altered values and flawed goals.

The model of union leader we propose for Romania is the authentic one the union members will have to know how to identify those people with the moral features and the desire to offer authentic leadership.

The study was conducted on a small sample and has a fairly large margin of error. At the same time, few questions were asked, which did not allow a detailed analysis. A deeper analysis is needed on the correlations between the authentic union leader and the management of the organization, respectively the political factors, and the pre-university school organizations being subordinated to the town halls. Other aspects worth exploring are the relationships between authentic leadership and individual and organizational performance, respectively.

\section{References}

[1] Agote L, Aramburu N, Lines R. Authentic leadership perception, trust in the leader, and followers' emotions in organizational change processes. The Journal of Applied Behavioral Science. 2016 [cited 2020 October 19]; 52(1):35-63. Available from: https://doi.org/10.1177/0021886315617531

[2] Avolio B, Gardner W, Walumbwa F, Luthans F, May D. Unlocking the mask: alook at the process by which authentic leaders impact follower attitudes and behaviors. The Leadership Quarterly. 2004 [cited 2020 October 19]; 15(6), 801-823. Available from: https://doi.org/10.1016/j.leaqua.2004.09.003

[3] Avolio BJ, Gardner WL. Authentic leadership development: Getting to the root of positive forms of leadership. The leadership quarterly. 2005 Jun 1 [cited 2020 October 19]; 16(3):315-318. Available from: https://doi.org/10.1016/i.leaqua.2005.03.001

[4] Băileşteanu G, Burz RD. Liderul. Timişoara: Editura Mirton; 2008. p.232, p.220.

[5] Dumitraşcu V. Liderii, arhetipuri şi roluri organizaţionale. Bucureşti: Editura Universitară; 2016. 228 p. 
[6] Elrehail H, Emeagwali OL, Alsaad A, Alzghoul A. The impact of transformational and authentic leadership on innovation in higher education: the contingent role of knowledge sharing. Telematics and Informatics. 2018 Apr 1 [cited 2020 October 19]; 35(1):55-67. Available from: https://doi.org/10.1016/j.tele.2017.09.018

[7] Gardner WL, Avolio BJ, Luthans F, May DR, Walumbwa FO. Can you see the real me? A self-based model of authentic leader and follower development. The Leadership Quarterly. 2005 [cited 2020 October 19]; 16:343-372. Available from: https://doi.org/10.1016/j.leaqua.2005.03.003

[8] George B, Sims P, McLean AN, Mayer D. Discovering your authentic leadership. Harvard business review. 2007 Feb 1[cited 2020 October 19]; 85(2):129. Available from: https://hbr.org/2007/02/discovering-yourauthentic-leadership

[9] Georgescu PI. Cultura organizațională. Motivația apartenenței la sindicat. Ploieşti : Editura Karta-Graphic; 2012.

[10] Hoch JE, Bommer WH, Dulebohn JH, Wu D. Do ethical, authentic, and servant leadership explain variance above and beyond transformational leadership? A meta-analysis. Journal of Management. 2018 Feb [cited 2020 October 19]; 44(2):501-529. Available from: https://doi.org/10.1177/0149206316665461

[11] Ilies R, Morgeson FP, Nahrgang JD. Authentic leadership and eudaemonic well-being: Understanding leader-follower outcomes. The leadership quarterly. 2005 Jun 1 [cited 2020 October 19];16(3):373-394. Available from: https://doi.org/10.1016/i.leaqua.2005.03.002

[12] Kiersch C, Peters J. Leadership from the Inside Out: Student Leadership Development within Authentic Leadership and Servant Leadership Frameworks. Journal of Leadership Education. 2017 Jan 1 [cited 2020 October 19]; 16(1): 148-168. Available from: https://doi.org/10.12806/V16/I1/T4

[13] Kouzes JM, Posner BZ. Adevărul despre leadership. London: B.M. I. Publishing. 2016.

[14] Leroy, H., Palanski, M.E. \& Simons, T. Authentic Leadership and Behavioral Integrity as Drivers of Follower Commitment and Performance. Journal of Business Ethics. 2017 [cited 2020 October 19]; 107: 255-264. Available from: https://doi.org/10.1007/s10551-011-1036-1

[15] Lyubovnikova J, Legood A, Turner N, Mamakouka A. How authentic leadership influences team performance: The mediating role of team reflexivity. Journal of Business Ethics. 2017 Mar 1 [cited 2020 October 19];141(1):59-70. Available from: https://doi.org/10.1007/s10551-015-2692$\underline{3}$ 
[16] Luthans F, Avolio B. Authentic leadership development. In: Cameron KS, Dutton SE, Quinn RE, editors. Positive organizational scholarshipFoundations of a new discipline. San Francisco, CA: Berrett-Koehler; 2003. pp. 241-258.

[17] Luthans F, Avolio BJ, Walumbwa FO, Li W. The psychological capital of Chinese workers: exploring the relationship with performance. Management and Organization Review. 2005 [cited 2020 October 19]; 1:249-271. Available from: https://doi.org/10.1111/j.1740-8784.2005.00011.x

[18] Luthans F, Youssef CM, Avolio BJ. Psychological capital. Oxford: Oxford University Press. 2007. 257 p.

[19] Luthans F, Avey JB, Patera JL. Experimental analysis of a web-based intervention to develop positive psychological capital. The Academy of Management Learning and Education. 2008 [cited 2020 October 19]; 7(2):209-221. Available from: https://doi.org/10.5465/AMLE.2008.32712618

[20] Palanski ME, Yammarino FJ. Impact of behavioral integrity on follower job performance: A three-study examination. The Leadership Quarterly. 2011 [cited 2020 October 19]; 22:765-786. Available from: https://doi.org/10.1016/j.leaqua.2011.05.014

[21] Popescu D. Introducere în comportamentul organizațional. Craiova: Editura Sitech. 2006.

[22] Rego A, Sousa F, Marques C, e Cunha MP. Authentic leadership promoting employees' psychological capital and creativity. Journal of Business Research. 2012 Mar 1 [cited 2020 October 19]; 65(3):429-437. Available from: https://doi.org/10.1016/i.jbusres.2011.10.003

[23] Rîlea V. Leadership. Teorii, modele şi aplicații. Iaşi: Editura Lumen. 2006. p.88.

[24] Rosanvallon P. La question syndicale. Paris: Hachette Pluriel. 1988.

[25] Sendjaya S, Pekerti A, Härtel C, Hirst G, Butarbutar I. Are authentic leaders always moral? The role of Machiavellianism in the relationship between authentic leadership and morality. Journal of Business Ethics. 2016 Jan 1 cited 2020 October 19]; 133(1):125-139. Available from: https://doi.org/10.1007/s10551-014-2351-0

[26] Shamir B, Eilam G. "What's your story?" A life-stories approach to authentic leadership development. The leadership quarterly. 2005 Jun 1 cited 2020 October 19];16(3):395-417. Available from: https://doi.org/10.1016/i.leaqua.2005.03.005

[27] Ştefan B, Liță CŞ, Mihalcea A. Organizațiile sindicale şi dilemele tranziției. Bucureşti: Editura BCS. 2001. 
[28] Todor C. Leadership total: ghidul liderului de succes. Cluj Napoca: Editura Risoprint. 2011.

[29] Zisu MA, Ralea MC. Leadership comunitar. Sibiu: Editura Universității Lucian Blaga din Sibiu. 2011.

[30] Zlate M. Leadership şi management. Iaşi: Editura Polirom. 2004.

[31] Walumbwa FO, Wang P, Wang H, Schaubroeck J, Avolio BJ. Psychological processes linking authentic leadership to follower behaviors. The Leadership Quarterly. 2010 [cited 2020 Sept 6]; 21(5): 901-914. (Retraction published 2014, The Leadership Quarterly, 25(5): 1071-1072). Available from: https://doi.org/10.1016/j.leaqua.2010.07.015

[32] Walumbwa FO, Avolio BJ, Gardner WL, Wernsing TS, Peterson SJ. Authentic leadership: Development and validation of a theory-based measure. Journal of Management. 2008 Feb [cited 2020 Sept 6]; 34(1):89-126. Available from: https://doi.org/10.1177/0149206307308913

[33] Walumbwa FO, Schaubroeck J. Leader personality traits and employee voice behavior: mediating roles of ethical leadership and work group psychological safety. Journal of Applied Psychology. 2009 Sep [cited 2020 Sept 6]; 94(5):1275. https://doi.org/10.1037/a0015848

[34] Wong CA, Spence Laschinger HK, Cummings GG. Authentic leadership and nurses' voice behaviour and perceptions of care quality. Journal of Nursing Management. 2010 [cited 2020 Sept 6]; 18: 889-900. Available from: https://doi.org/10.1111/j.1365-2834.2010.01113.x

[35] Youssef CM, Luthans F. Positive organizational behavior in the workplace: The impact of hope, optimism, and resilience. Journal of Management 2007[cited 2020 Sept 6]; 33(5):774-800. Available from: https://doi.org/10.1177/0149206307305562 